\title{
A Note on Bank Capital Buffer, Portfolio Risk and Business Cycle
}

\author{
Banka Sermaye Tamponu, Portföy Riski ve Iş Çevrimleri Üzerine Bir Not
}

\author{
Sine KONTBAY BUSUN ${ }^{1}$, Adnan KASMAN ${ }^{2}$
}

\begin{abstract}
This paper examines the impact of business cycle on bank capital buffer and portfolio risk using quarterly data for commercial banks operating in the Turkish banking industry for the period 2002Q1-2012Q2. The results indicate that the business cycle and capital buffer are negatively related, suggesting that banks' capital buffers increase (decrease) as economic conditions worsen (improve). The results also indicate that banks default risk has a positive and significant impact on capital buffer, while capital buffer has a negative and significant impact on default risk. The results further suggest that banks do not benefit from revenue diversification and larger banks hold less capital buffer. Finally, banks that earn higher profit hold more capital buffer and banks that make more profit are exposed to less risk.
\end{abstract}

Keywords: Capital buffer, portfolio risk, business cycle, Turkish banking

\section{INTRODUCTION}

Banking sector is one of the most regulated financial sectors of an economy due to the concerns on the economic stability. The main instrument that is used to regulate the banking sector is bank capital as it can amplify the effect of economic shocks on lending. With an aim to safeguard the international financial system and banking sector from failing, in 1988, an international standard for capital regulations of banking sector is established with Basel Accord (Basel I) to guarantee that banks hold sufficient capital against the risks associated with its lending and investment decisions and to better insure against the business cycle fluctuations and the market risks. For the countries that adopt this accord, banks are required to hold $8 \%$ of their Risk Weighted Assets (RWA) in capital. The Capital requirements become more risk sensitive subsequent to the changes made in Basel Accord (1988). In case of failure to meet regulatory minimum criteria a supervisory

\begin{abstract}
ÖZET
Bu çalışmada iş çevrimlerinin bankaların sermaye tamponları ve portföy riskleri üzerindeki etkisi, Türk bankacilık sektöründe faaliyet gösteren ticari bankaların 2002Q1:2012Q2 dönemi için çeyreklik veriler kullanarak incelenmiştir. Çalışma bulguları iş çevrimleri ile sermaye tamponu arasında ters yönlü bir ilişkiye işaret etmekte; bir diğer deyişle bankaların sermaye tamponlarının ekonomik koşullar kötüleştikçe (iyileştikçe) arttığını (azaldığını) göstermektedir. Çalışmanın bir başka bulgusu da bankaların temerrüt riskinin sermaye üzerindeki etkisinin pozitif, sermaye tamponunun temerrüt riski üzerindeki etkisinin ise negatif ve istatistiksel olarak anlamlı olduğu yönündedir. Ayrıca, Türk Bankacılık sistemindeki ticari bankaların gelir kaynaklarındaki çeşitlilikten yararlanamadıkları, büyük bankaların daha az sermaye tamponu tuttuğu ve son olarak da; karlılık oranı daha yüksek olan bankaların daha fazla sermaye tamponu tutarken, yine bu bankların daha az temerrüt riski taşıdığı da çalışmanın diğer bulguları arasındadır.
\end{abstract}

Anahtar Kelimeler: Sermaye tampon, portföy riski, iş çevrimleri, Türk bankacilık sektörü

intervention is implemented to guide the banks with the new arrangements in Basel II (2004).

In practice, banks tend to hold more than the regulatory minimum level of its RWA in capital. The excess capital above the regulatory minimum is called capital buffer. Even though holding idle capital is costly, banks tend to hold capital buffer as a cushion against the market imperfections such as risks and unexpected losses associated with economic fluctuations, lending and investment activities (Jokipii and Milne, 2008). Holding capital above the required minimum enables banks to take advantage of profitable opportunities arise, and strengths the impression of the bank in the market as capital buffer is also perceived as an indicator of bank's financial health.

The aftermath of global economic crisis in 2008 increased the concerns over the adequacy of minimum capital requirements brought by Basel II (2004) in many countries as it increased dependence 
of capital buffer on business cycle fluctuations. If the capital buffer fluctuates counter-cyclically over the business cycle, banks' capital buffer decreases in economic upturns and increases as economy downturns. Therefore, meeting the regulatory minimum capital requirement becomes more costly for poorly capitalized banks in busts and they would prefer raising capital buffer by cutting lending to the market rather than through its costlier alternative of issuing new equity. That's, countercyclical fluctuation of capital buffer magnifies the impact of economic shocks on lending. Hence, the cyclical behavior of capital buffer has an important impact on economic stability. These concerns over cyclical behavior of capital buffer brought new capital reforms in Basel III and negative capital buffer requirement restricted within a range of $0-2.5 \%$ imposed on banks.

The counter-cyclical behavior of capital buffer is observed in several empirical studies. Ayuso et. al. (2004) focused on the Spanish banks and found that banks' capital buffer fluctuate counter-cyclically over business cycle for the period 1986-2000. Stolz and Wedow (2011) studied the German Banks for the period of 1993-2004 and found similar results as in Ayuso et. al. (2004). Their findings further show that low capitalized banks' risk-weighted assets do not decrease in recessions suggesting that they do not avoid from lending in recessions. Boucinha (2008) examined the capital holdings of Portuguese banks above the required minimum and found evidence in favor of a negative business cycle effect on capital buffer. Japikii and Milne (2008) found that capital buffer of commercial and savings banks, and of large banks fluctuate counter-cyclically while of cooperative and smaller banks fluctuate pro-cyclically in the EU15 over the period of 1997-2004. Shim (2013) found that capital buffer of banks in the US have a negative co-movement with cycle. They also find evidence in favor of an negative relationship between business cycle and default risk. The studies concerning the cyclical behavior of capital buffer in developing countries' banking sectors, on the other hand, are not many. Garcia-Suaza, et al. (2012), found evidence in favor of a negative and significant comovement of capital buffers with the business cycle for Colombian banks. Tabak, et al. (2011) examined the capital buffers held by banks in Brazil over the period 2000-2010 and found that capital buffer fluctuates counter-cyclically over the business cycle.

The aim of this study is to analyze the cyclical behavior of capital buffers held by commercial banks operating in the Turkish banking industry. Following the 2000-2001 economic crisis, Turkey adopted
"Transition to a Strong Economy" program and the "Banking Sector Restructuring and Rehabilitation Program" that brought some new regulations in force that are in line with the international regulatory standards. Banking Regulation and Supervision Agency (BRSA) began operation in 2000 as the only regulation and supervision authority in the banking sector. As a result of the transition process that the country's financial system and banking sector have gone through in the course of the last decade; state banks were restructured and become more profitable, the private capital participation was encouraged to strength the private banking system, the capital structure of private banks was regulated to limit their market risk. Before BRSA adopted Basel II in 2012, Turkey has implemented its own version of Basel II in which BRSA determined the risk weight for the foreign currency reserves held with the Central Bank of Turkey (CBT) as zero. Currently, Turkey is the only OECD country whose banking system did not need any financial support from public following the 2008 crisis. Capital Adequacy Ratio of the banks operating in Turkey is recorded as 17.4\% in March 2013. Considering this recent history of Turkish banking system, we believe that assessing the determinants of capital buffer and risk profile of the banking sector, and conducting research on the cyclical behavior of banks' capital buffer in Turkey for this time period will shed some light on the possible outcomes of Turkey's adoption of Basel II, its accession to Basel III and its effect on banks' capital. There is only limited number of studies on the cyclical behavior of capital buffer in the related literature. Previous research on this issue is mostly on developed countries' banking sectors. Hence, examining cyclical behavior of capital buffer and risk for the banking market of a developing country contributes to the literature. To our best knowledge, the study of Gursoy and Atici (2012) is the only paper focusing on the determinants of capital buffer held by banks in Turkey. Our study departs significantly from Gursoy and Atici's (2012) work as we consider a simultaneous relationship between capital buffer and banking risk using quarterly data. Moreover, our focus is on the last decade of the Turkish banking sector. We believe that focusing on a narrower and a better specified time period will be more informative for the current policy making decisions as the Turkish banking sector has gone through important structural changes during the last decade and had a chance to observe the initial results of these regulations on the financial sector after the 2008 global economic meltdown. 
The remainder of the paper is organized as follows. Section 2 introduces empirical specification and methodology. Section 3 presents data and empirical results. Section 4 concludes.

\section{METHODOLOGY}

We employ a partial adjustment framework for capital buffer and risk equations with an aim to analyze the impact of business cycle on banks' capital buffer and risk taking decision. Following the previous literature (Ayuso et. al. 2004; Jokipii and Milne, 2008; Shim 2013), the partial adjustment framework is specified as follows:

$$
\begin{aligned}
& \operatorname{BBUF}_{\mathrm{i}, \mathrm{t}}=\alpha\left(B U F_{i, t}^{*}-B U F_{i, t-1}\right)+\eta_{i}+u_{i, t} \\
& \Delta \operatorname{RISK}_{\mathrm{i} \mathrm{t}}=\beta\left(\mathrm{RISK}_{i, t}^{*}-\mathrm{RISK}_{i, t-1}\right)+\eta_{i}+\varepsilon_{i, t}
\end{aligned}
$$

where $B U F_{i, t}$ and $R I S K_{\mathrm{i}, \mathrm{t}}$ represent the actual capital buffer and risk of bank i at time t, $B U F_{i, t}^{*}$ and $R_{I S K_{i, t}^{*}}^{*}$ represent the optimum capital buffer and risk of bank i at time t. The coefficients $\alpha$ and $\beta$ measure the speed of adjustment of actual capital buffer and risk variables towards their optimum level. We allow for bank-specific effects $\eta_{i}$. The disturbance terms $u_{i, t}$ and $\varepsilon_{i, t}$ are assumed to be independently distributed across banks with a zero mean. By adding $B U F_{i, t-1}$ to both sides of Eq. (1) and $R I S K_{i, t-1}$ to both sides of Eq.(2), we obtain the following specifications:

$$
\begin{aligned}
& B U F_{\mathrm{i}, \mathrm{t}}=\alpha B U F_{i, t}^{*}+(1-\alpha) B U F_{i, t-1}+\eta_{i}+u_{i, t}(3) \\
& \operatorname{RISK}_{\mathrm{i}, \mathrm{t}}=\beta R I S K_{i, t}^{*}+(1-\beta) R I S K_{i, t-1}+\eta_{i}+\varepsilon_{i, t} \text { (4) }
\end{aligned}
$$

The optimum level of capital buffer $\left(B U F_{i, t}^{*}\right)$ and risk $\left(R I S K_{i, t}^{*}\right)$ are not observable. Hence, we instrumented these unobservable variables with business cycle and bank specific characteristics as suggested by the literature (Jokipii and Milne, 2008; Stolz and Medow, 2011; Shim, 2012; Garcia-Suaza et. al. 2012). We also include $R I S K_{\mathrm{it}}$ variable to buffer equation and $B U F_{\mathrm{it}}$ variable to risk equation since the risk profile of banks and the level of capital buffer are interdependent and simultaneously determined (Shrieves and Dahl, 1992; Rime, 2001; Shim, 2013). Therefore, the empirical specifications that control the simultaneous relationship between capital buffer and risk regressions can be specified as follows:

$$
\begin{aligned}
& B U F_{\mathrm{i}, \mathrm{t}}=\alpha_{0}+\alpha_{1} B U F_{\mathrm{it}-1}+\alpha_{2} R_{I S K_{i, t}}+ \\
& \alpha_{3} C Y C L E_{t}+\delta^{\prime} X_{i, t}+\eta_{i}+u_{i, t}
\end{aligned}
$$

$$
\begin{aligned}
& \operatorname{RISK}_{\mathrm{it \textrm {t }}}=\beta_{0}+\beta_{1} \text { RISK }_{\mathrm{i \textrm {t } - \mathrm { l }}}+\beta_{2} B U F_{i, t}+ \\
& \beta_{3} C Y C L E_{t}+\phi^{\prime} Y_{i, t}+\eta_{i}+\varepsilon_{i, t}
\end{aligned}
$$

where measures the business cycle at time . $X_{i, t}$ and $Y_{i, t}$ are the vectors of bank-specific control variables for bank $i$ at time $t$.

Estimating Eq. (5) and Eq. (6) with pooled OLS presents an endogeneity problem since the bankspecific effects affect $B U F_{\mathrm{it}}$ and $R I S K_{\mathrm{i}, \mathrm{t}}$ in one period, they presumably affected them also in the previous period. To solve the endogeneity problem, Arellano and Bond (1991) developed a difference GMM estimator for the coefficients in Eq. (5) and Eq. (6) where the lagged levels of the regressors are the instruments for the equation in first differences. However, Arellano and Bover (1995) and Blundell and Bond (1998) suggest to difference the instruments instead of the regressors in order to make them exogenous to the fixed effects. This leads from the difference GMM to the system GMM estimator, which is a joint estimation of the equation in levels and in first differences.

\section{DATA AND EMPIRICAL RESULTS}

\subsection{Data}

This paper uses unbalanced panel data of 27 commercial banks operating in the Turkish banking industry for the period 2002:Q1-2012Q:2. Our dataset was built on information from the quarterly reports of individual banks, which include their balance sheets and income statements, obtained from the Banks Association of Turkey. The data were reviewed for reporting errors, inconsistencies, missing values and extreme values. Five banks were dropped from the sample due to the missing values or inconsistencies. However, our sample represents $98 \%$ of the total assets of the Turkish banking system.

The dependent and bank-specific variables used in the estimation of Eq. (5) and Eq. (6) are defined as follows:

Capital buffer (BUF): Following Jokipii and Milne (2008), capital buffer is defined as the amount of actual capital ratio of banks exceeding the $8 \%$ regulatory minimum level of capital in Turkey.

RISK: The ratio of non-performing loans to total loans is used as a measure of bank risk. This measure has been commonly used to proxy risk in the banking literature (Fiordelisi et al., 2011; Shim, 2013).

Business Cycle (CYCLE): The relationship between capital buffer (risk) and business cycle is investigated by using HP filtered GDP growth as a proxy for the 
business cycle with (Hodrick and Prescott, 1997).

Diversification (DIVER): The banks' revenue diversification is controlled in the regression using the share of non-interest income in total income of banks.

Bank Size (LTA): The natural logarithm of total assets is used to control for bank size in the regression.

Profitability (ROA): The return on assets is used to control the impact of profit on buffer and risk.

Loan loss reserve (LLR): Loan loss reserve ratio is a quality indicator of the loan portfolios of banks as it measures the amount of reserves banks hold to cover potential losses in their loan portfolios.

Asset growth (AGROWTH): Asset growth rate is also included in bank specific variables.

Table 1 reports summary statistics of the key and control variables.

Table 1: Summary Statistics of Key and Bank Specific Variables

\begin{tabular}{|c|c|c|c|c|}
\hline Variable & Mean & $\begin{array}{c}\text { Standard } \\
\text { Deviation }\end{array}$ & Minimum & Maximum \\
\hline BUF & 0.055 & 0.063 & -0.058 & 0.836 \\
\hline RISK & 0.072 & 0.127 & 0 & 1.537 \\
\hline CYCLE & -0.000 & 2.14 & -7.07 & 4.27 \\
\hline DIVER & 0.193 & 0.134 & -0.638 & 0.749 \\
\hline SIZE & 8.219 & 1.869 & 3.628 & 11.564 \\
\hline ROA & 0.946 & 1.564 & -17.611 & 9.389 \\
\hline LLR & 92.626 & 170.64 & -0.312 & 1537.332 \\
\hline AGROWTH & 0.0628 & 0.1625 & -0.582 & 2.023 \\
\hline
\end{tabular}

(Note: BUF, RISK, CYCLE, DIVER, SIZE, ROA, LLR and AGROWTH stand for capital buffer, the ratio of non-performing loans to total loans, GDP growth rate, the ratio of non-interest income to total income, natural logarithm of total assets, return on assets, loan loss reserves and asset growth rate, respectively. LLR is in millions of USD.

\subsection{Empirical Results}

The empirical models specified in Eq. (5) and Eq.(6) are estimated using two-step system Generalized Method of Moments (GMM) as suggested by Arellano and Bover (1995) and Blundell and Bond (1998). The regression results for both models are reported in Table 2. At the bottom of the table, we report specification test results for the GMM estimations'. According to these tests all GMM equations are properly specified.

Table 2 indicates the impact of GDP growth (CYCLE) along with some bank-specific control variables on capital buffer and non-performing loans ratio. HP filter is applied to GDP growth variable to obtain the CYCLE variable. The result shows that the coefficient of CYCLE on capital buffer is significantly negative, suggesting that the capital buffer in Turkey fluctuates counter-cyclically over the business cycle. This finding indicates that banks' capital buffers increase (decrease) as economic conditions worsen (improve) and is also in line with the findings of previous studies (Jokipii and Milne, 2008; Shim, 2013). As for the risk equation, the result shows that CYCLE and non-performing loans ratio (RISK) are negatively related. This result implies when the Turkish economy is in a boom, the non-performing loans ratio and -in turn- the risk perception of banks fall, which leads to a credit expansion to the market through increased bank loans without capital expansion and, therefore, banks would be more open to risks (higher nonperforming loans ratio) when the economic boom reverts.

The positive and significant coefficient of lagged capital buffer indicates that the cost of capital adjustment is relevant and quite high (0.73) for banks in Turkey. The lagged capital buffer variable is also a proxy for the speed of adjustment of today's capital buffer to the capital buffer in previous period and hence, an indicator for banks' access to the capital markets as banks with an easy access to capital markets can adjust their current capital buffer to previous period faster. Therefore, the higher the coefficient estimate of lagged capital buffer is, the faster the speed of bank capital adjustment of current capital buffer. Similarly, the positive and significant coefficient on lagged risk variable demonstrates that current non-performing loans ratio adjusts to previous period's non-performing loans ratio at a rate faster than the speed of adjustment of capital buffer. The results also indicate that non-performing loans ratio has a positive and significant impact on capital buffer, suggesting that banks with higher risk have higher capital buffer. In contrast to the capital buffer equation, we observe that capital buffer has a negative and significant impact on non-performing loan ratio.

The positive and significant coefficient on diversification in both regressions indicates that banks do not benefit from income diversification in Turkey. That is, as banks diversify their non-interest share income sources, the risk associated with nonperforming loans ratio increases and this increase in risk leads banks to hold higher capital buffer. The results show that coefficient of bank size (SIZE) is negative and significant for capital buffer equation; suggesting that larger banks hold less capital buffer as the bank size grows larger. This result is in line with the "too big to fail" hypothesis such that large 
banks would be recipient of government support in case of a financial difficulty and in return they tend to hold less capital buffer. The banks size is not relevant for banks' exposure to risk of non-performing loans. The return on assets (ROA) is used as proxy for bank profitability. The coefficient of this variable is positive and significant for capital buffer equation which implies that banks that earn higher profit hold more capital buffer. Particularly, when it is costly to raise capital from capital markets, banks tend to raise capital buffer through retained earnings and therefore, it is easier to increase capital if the bank is profitable. We estimated a negative and significant relationship between the return on assets and risk; indicating that as banks make more profit they are exposed to less risk of non-performing loans.

Loan loss reserve (LLR) has insignificant coefficient in both regressions. Capital buffer is expected to decrease as loan loss reserves increases. However, this increase is negligible as the coefficient estimate is very small in magnitude and not significant. Lastly, banks' total asset growth rate has a significant negative impact on capital buffer and non-performing loans ratio. This implies that when banks accumulate more assets, the ratio of risky assets in banks' portfolios increases and therefore the required minimum that needs to be held in capital increases and exhausts the capital buffer.

\section{CONCLUSIONS}

This paper examines the cyclical behavior of capital buffers held by banks in Turkey and addresses the determinants of capital buffer and the risk associated with non-performing loans over the period 2002:Q12012Q:2

The results suggest that both capital buffer and risk of banks in Turkey fluctuate counter-cyclically over the business cycle. The significant negative impact of business cycle on capital buffer implies that banks in Turkey are short sighted. That is, banks do not add to their capital buffer while they are increasing the credit supply to the market in an economic boom. Therefore, counter-cyclical fluctuation of capital buffer is expected to lead credit crunch during economic downturns and magnifies the impact of economic shocks on lending. This behavior is also closely related with the risk perception of banks that fall during economic upturn. This indicates that the concerns associated with the Capital Adequacy Ratio requirement of Basel II are also valid for Turkey. This countercyclical behavior of capital buffer indicates that adoption of Basel III is essential for the Turkish Banking system since Basel III imposes negative capital buffer requirement restricted within a range of $0-2.5 \%$.
Table 2: Determinants of Capital Buffers and Risk for Turkish Commercial Banks (2002:Q1-2012Q:2)

\begin{tabular}{|c|c|c|}
\hline Variable & $\begin{array}{l}\text { Dependent variable: } \\
\text { Capital Buffer }\end{array}$ & $\begin{array}{c}\text { Dependent } \\
\text { variable: } \\
\text { Risk }\end{array}$ \\
\hline CYCLE & $\begin{array}{c}-0.0002^{* *} \\
(0.0001)\end{array}$ & $\begin{array}{c}-0.0011^{* * *} \\
(0.0000)\end{array}$ \\
\hline BUF $_{t-1}$ & $\begin{array}{c}0.7301^{* * * *} \\
(0.0071)\end{array}$ & \\
\hline RISK & $\begin{array}{l}0.0128^{* *} \\
(0.0036)\end{array}$ & \\
\hline RISK $_{t-1}$ & & $\begin{array}{c}0.8291^{* * *} \\
(0.0043)\end{array}$ \\
\hline BUF & & $\begin{array}{c}-0.0138^{* *} \\
(0.0056)\end{array}$ \\
\hline DIVER & $\begin{array}{c}0.0426^{* * *} \\
(0.0019)\end{array}$ & $\begin{array}{l}0.0042^{* *} \\
(0.0019)\end{array}$ \\
\hline SIZE & $\begin{array}{c}-0.0034^{* * *} \\
(0.0003)\end{array}$ & $\begin{array}{c}0.0000 \\
(0.0002) \\
\end{array}$ \\
\hline $\mathrm{ROA}$ & $\begin{array}{l}0.0058^{* * *} \\
(0.0001)\end{array}$ & $\begin{array}{c}-0.0039^{* * *} \\
(0.0003)\end{array}$ \\
\hline LLR & $\begin{array}{l}-0.0000 \\
(0.0000)\end{array}$ & $\begin{array}{l}0.000 \\
(0.000)\end{array}$ \\
\hline AGROWTH & $\begin{array}{l}-0.0633^{* * *} \\
(0.0031)\end{array}$ & $\begin{array}{c}-0.0115^{* * *} \\
(0.0009)\end{array}$ \\
\hline Constant & $\begin{array}{c}0.0322^{* * * *} \\
(0.0022)\end{array}$ & $\begin{array}{c}0.0111^{* * *} \\
(0.0016)\end{array}$ \\
\hline M1 (p-value) & 0.002 & 0.173 \\
\hline M2 (p-value) & 0.723 & 0.312 \\
\hline $\begin{array}{c}\text { Sargan/Hansen } \\
\text { (p-value) }\end{array}$ & 0.971 & 0.148 \\
\hline
\end{tabular}

(Note: *** and ** denote significance level at $1 \%$ and $5 \%$, respectively. The Sargan/Hansen is a test of the over-identifying restrictions for the GMM estimators. M1 and $\mathrm{M} 2$ are tests for the first-order and second-order serial correlation. The instrument matrix is collapsed by combining instruments through addition into smaller sets, 20 lags are used as instruments for each period. The CYCLE variable represents the HP-filtered GDP growth. The estimations are also run by approximating the CYCLE variable with GDP growth itself. The results are robust to the changes in the definition of the varialbe and available from authors upon request.)

We also controlled for the simultaneous effect of capital buffer and risk in our estimations. The results indicate that non-performing loans ratio has a positive and significant impact on capital buffer, while capital buffer has a negative and significant impact on nonperforming loan ratio. This suggests that banks with higher risk have higher capital buffers and as the capital buffers that banks hold increase, risks associated with non-performing loans decrease. Therefore, capital buffer can be considered as a cushion against the increased non-performing loans ratio during economic downturns. 
We also examined the marginal effect of bank characteristics on the changes in capital buffer and risk. We found that banks do not benefit from diversifying their non-interest share income sources. Considering the size effect, we found evidence in favor of "too big to fail" hypothesis as larger banks are estimated to hold less capital buffer. We do not observe a significant size effect on risk. Banks that earn higher profit hold more capital buffer and banks that make more profit are exposed to less risk of nonperforming loans. Loan loss reserve has a negligible impact on both capital buffer and risk regressions. 


\section{END NOTES}

${ }^{1}$ The Sargan test is a test on whether the instruments are uncorrelated with the error term. Moreover, the ArellanoBond test results also require significant $\mathrm{AR}(1)$ serial correlation and lack of $\mathrm{AR}(2)$ serial correlation.

\section{REFERENCES}

Arellano, M. ve Bond, S.R. (1991) "Some Tests of Specification For Panel Data: Monte Carlo Evidence and An Application to Employment Equations" Review of Economic Studies, 58:277-297.

Arellano, M. ve Bover, O. (1995) "Another Look At The Instrumental Variables Estimation of Error Components Models" Journal of Econometrics, 68:29-51.

Ayuso, J., Perez, D. ve Saurina, J. (2004) "Are Capital Buffers Pro-Cyclical? Evidence From Spanish Panel Data" Journal of Financial Intermediation, 13: 249-264.

Boucinha, M. (2008) "The Determinants of Portuguese Banks' Capital Buffers" Banco de Portugal, Economics and Research Department, Working Papers Series.

Blundell, R. ve Bond, S.R. (1998) "Initial Conditions and Moment Restrictions in Dynamic Panel Data Models" Journal of Econometrics, 87: 115-143.

Fiordelisi F., Marques-Ibanez, D. ve Molyneux, P. (2011) "Efficiency and Risk in European Banking" Journal of Banking and Finance, 35:1315-1326.

Gursoy, G. ve Atici, G. (2012) "The Determinants of Capital Buffer in the Turkish Banking System" International Business Research, 6:224-234.

Garcia-Suaza A.F., Gomez-Gonzalez, J.E., Pabon, A.M. ve Tenjo-Galarza, F. (2012) "The Cyclical Behaviour of Bank Capital Buffers in An Emerging Economy: Size Does Matter" Economic Modelling, 29: 1612-1617.
Hodrick, R.J. ve Prescott, E.C. (1997) "Post-war US Business Cycles: an Empirical Investigation" Journal of Money, Credit and Banking, 29:1-16.

Jokipii, T. ve Milne, A. (2008) "The Cyclical Behavior of European Bank Capital Buffers" Journal of Banking and Finance, 32:1440-1451.

Rime, B. (2001) "Capital Requirements and Bank Behavior: Empirical Evidence For Switzerland" Journal of Banking and Finance, 25:789-805.

Shim J. (2013) "Bank Capital Buffer and Portfolio Risk: The Influence of Business Cycle and Revenue Diversification" Journal of Banking and Finance, 37:761772

Shrieves, R.E. ve Dahl, D. (1992) "The Relationship Between Risk and Capital in Commercial Banks" Journal of Banking and Finance, 16: 439-457.

Stolz S. ve Wedow, M. (2011) “Banks' Regulatory Capital Buffer and The Business Cycle: Evidence For Germany" Journal of Financial Stability, 7: 98-110.

Tabak, B.M., Noronha, A.C. ve Cajueiro, D.O. (2011) "Bank Capital Buffers, Lending Growth And Economic Cycle: Empirical Evidence For Brazil" $2^{\text {nd }}$ BIS CCA Conference On "Monetary Policy, Financial Stability And The Business Cycle, 12-13 May 2011, Ottawa. 
